World Population Policies 

John F. May

\section{World Population Policies}

Their Origin, Evolution, and Impact

囪 Springer 


\author{
John F. May \\ The World Bank \\ 1818 H Street NW. \\ Washington, DC 20433 \\ USA
}

ISBN 978-94-007-2836-3

ISBN 978-94-007-2837-0 (eBook)

DOI 10.1007/978-94-007-2837-0

Springer Dordrecht Heidelberg New York London

\author{
Library of Congress Control Number: 2012934457
}

(C) Springer Science+Business Media B.V. 2012

This work is subject to copyright. All rights are reserved by the Publisher, whether the whole or part of the material is concerned, specifically the rights of translation, reprinting, reuse of illustrations, recitation, broadcasting, reproduction on microfilms or in any other physical way, and transmission or information storage and retrieval, electronic adaptation, computer software, or by similar or dissimilar methodology now known or hereafter developed. Exempted from this legal reservation are brief excerpts in connection with reviews or scholarly analysis or material supplied specifically for the purpose of being entered and executed on a computer system, for exclusive use by the purchaser of the work. Duplication of this publication or parts thereof is permitted only under the provisions of the Copyright Law of the Publisher's location, in its current version, and permission for use must always be obtained from Springer. Permissions for use may be obtained through RightsLink at the Copyright Clearance Center. Violations are liable to prosecution under the respective Copyright Law.

The use of general descriptive names, registered names, trademarks, service marks, etc. in this publication does not imply, even in the absence of a specific statement, that such names are exempt from the relevant protective laws and regulations and therefore free for general use.

While the advice and information in this book are believed to be true and accurate at the date of publication, neither the authors nor the editors nor the publisher can accept any legal responsibility for any errors or omissions that may be made. The publisher makes no warranty, express or implied, with respect to the material contained herein.

Printed on acid-free paper

Springer is part of Springer Science+Business Media (www.springer.com) 
To my wife, Anne, this book is lovingly dedicated 



\section{Foreword}

While concern about the balance between population growth and available resources has been around since the time of the Rev. Thomas Malthus more than 200 years ago, public policies to influence population variables have a much more recent provenance. Malthus despaired, of course, that unless the increase in human numbers could be brought under control, food production would inevitably fall further and further behind population growth with the result being ever-increasing hunger and poverty for a great majority of people. He urged the institutions of his time to take action to slow down the growth of human numbers, although the means for doing so were few and the response was minimal.

Modern population policies, at least at a national level, had to wait 150 years, until the early 1950s when, as a result of the first round of post-World War II censuses, UN demographers suddenly came to realize that populations were growing at unprecedented rates, particularly in Asia. Concern began to spread about an impending "population explosion" and, echoing Malthus's earlier alarms, international leaders began calling for action to stem this rapid growth. The year 1952 might be identified as the beginning of an international population "movement" that brought about increasingly collective action among nations over the next 40 years. In 1952 two important international institutions were born - the International Planned Parenthood Federation and the Population Council - that arguably led the drive for collective global action over the next 20 years; and India announced the world's first national population policy - a commitment to reduce birth rates through a national family planning effort.

It would be nice to report that the movement that sprang from these early seeds flourished and grew with uniform speed and impact throughout the world, but as John May eloquently demonstrates in this volume, that was hardly the case. Through the first 20 years after 1952, global recognition of a population problem grew rather slowly and only a few nations, nearly all of them in Asia, decided to take action to slow down demographic growth. Among those that began to take action in the 1960s were India's South Asian neighbors, Sri Lanka and Pakistan, followed soon thereafter 
by Singapore, Taiwan and South Korea, Indonesia and Thailand. By the late 1960s, many of the larger Asian nations had adopted population policies, nearly all of them consisting principally of family planning service programs.

While the programs in East and Southeast Asia for the most part thrived and were quite successful in bringing birth rates down, those that had started a decade or so earlier in India and Pakistan did not. The South Asian programs achieved very disappointing results and, perhaps because they were the earliest and the most closely studied, gave rise to increasing pessimism in many circles about how effective family planning programs by themselves could be in reducing fertility. Many academic demographers, long skeptical about how enthusiastically individual couples would respond to voluntary family planning programs, saw in the disappointing South Asian results confirmation that much more was needed to stimulate demand for smaller families. Thus, calls began for measures "beyond family planning" - actions to stimulate the desire for smaller families or to directly reward those who achieved them. These ranged from relatively indirect parallel measures such as improving girls' access to education and reducing under-five mortality rates, to more active interventions such as monetary incentives to use contraceptives or to limit births, to more draconian actions including rationing access to housing based on small family size or paying people to undergo sterilization. Policymakers in India had become so frustrated by the failure of voluntary family planning efforts that they turned increasingly to such solutions, culminating in the coercive sterilization campaigns during the so-called Emergency of 1975-1977. Chinese authorities, with their "One-Child Policy", resorted to similarly coercive policies shortly thereafter.

Alongside the skeptical demographers were two prominent groups of economists who were also dubious about the international population movement. One group challenged the Malthusian notion that rapid population growth was, in fact, an impediment to economic growth and development. The other challenged the belief that voluntary family planning would have significant appeal to low income, primarily rural households in developing countries for whom large families represented what they perceived to be a rational response to poverty, the need for household and agricultural labor, and for whom children represented a source of security in old age. Given their prominence and influence as advisers to governments, such economists played an important role in counteracting the advice many governments were receiving from elsewhere in the international community.

John May tells the story of how the series of international population conferences that ran from Bucharest in 1974, through Mexico City in 1984, to Cairo in 1994 gradually created a global consensus in favor of a broad developmental approach to population policy, an approach that emphasized: the empowerment of women, improvements in maternal and young child health, voluntary family planning embedded in a broader reproductive health framework, and the protection of individual reproductive rights - the so-called Cairo Consensus. He shows how the success of voluntary programs in many countries, as well as the excesses that produced human rights abuses in others, contributed to this consensus and how demographic changes over the past two or three decades have produced new concerns and 
new policy discussions about excessively low birth rates, rapid population aging, and high rates of international migration. This book tells how difficult these issues are in developed countries as population aging challenges the survival of the post-industrial socioeconomic model and immigration is often perceived as a threat to national identities.

Today, only China can be said to maintain a population policy that falls outside the broad framework of the Cairo Consensus. While spectacularly successful in reducing fertility (China's fertility rate is well below the replacement level of approximately two children per woman), there have been serious unanticipated consequences of China's policy, namely, a badly skewed sex ratio resulting in many more boys than girls; and a population that is now aging so rapidly as to raise serious concerns about future labor supply to sustain China's impressive economic growth.

This book would be important if it did nothing more than explain how population policies have evolved and what their impacts have been, for it represents by far the most exhaustive and comprehensive treatment of this historically important subject written to date. But it does much more. It highlights the paramount importance of understanding underlying demographic trends when assessing the development prospects of any country. As such, it offers a much needed long-term perspective that is so important for any policymaker. In this sense, it is of particular importance for what it has to say to governments in sub-Saharan Africa that are today still facing the problem of extremely high fertility and rapid population growth. Africa remains the last region still experiencing runaway population growth and governments there are beginning to come to grips with the problem. The countries of Southern Africa are in the lead but many other states are now taking actions that are likely to bear results over the next 15-20 years. Only Central and West African governments remain resistant to taking firm steps to confront their unsustainably high fertility. This book, written by a man who has spent many years working in the region and with first-hand experience with its problems, provides important insights to guide population policy development in Africa and one hopes that African leaders will be guided by the wisdom and advice contained in this volume.

Dr. Steven W. Sinding Former Director General International Planned Parenthood Federation Manchester, Vermont 



\section{About the Author}

John F. May, a Belgian national, is a Lead Demographer at the World Bank, and a specialist in population policies and programs. Prior to joining the World Bank in 1997, he worked on many population projects around the world for UNFPA, UNICEF, USAID, and the International Union for the Scientific Study of Population (IUSSP). He was posted in Haiti, West Indies, and New Caledonia, South Pacific for the United Nations. He came to the US in 1987 and was appointed Senior Scientist at The Futures Group International, a consulting firm offering services in population and HIV/AIDS modeling, policy, and program design. In 1991-1992, he spent a year as a Visiting Scholar at the Population Reference Bureau (PRB) and was a PRB Visiting Scholar again in 2006, 2007, and 2011. He is also an Adjunct Professor of Demography at Georgetown University, Washington, DC. He earned a BA in Modern History (1973) and a MA in Demography (1985) from the Catholic University of Louvain (Belgium), and a Doctorate in Demography (1996) from the University of Paris-V (Sorbonne). 



\section{Disclaimer}

The findings, interpretations, and conclusions expressed herein are those of the author and do not necessarily reflect the views of the Board of Executive Directors of the World Bank or the governments they represent. 



\section{Acknowledgments}

This book has been long in the making. The initial idea was suggested many years ago by Jean-Claude Chesnais. He had in mind a comprehensive volume on world population policies that would be based on concrete examples of how population policies are actually implemented. Thereafter, he read the entire manuscript, and so did Karar Zunaid Ahsan, William P. Butz, Barbara Crane, Hazel Denton, Anton Dobronogov, Léon Gani, Pierre Gschwindt de Gyor, Karen Hardee, and Françoise May. To all of them, I express my deepest gratitude for their invaluable comments.

Thanks are due to my editors at Springer, Evelien Bakker and Bernadette DeelenMans, who supported the project from day one and helped bring it to completion.

Several anonymous reviewers provided feedback at different stages during the preparation of the book and I would like to acknowledge their contributions.

The Population Reference Bureau (PRB) offered a quiet haven to think and write during several sabbatical periods, for which I am most grateful.

Particular thanks are due to four outstanding research assistants who provided major support, namely Angela M. Kao, Natalie Menser, Jane Remme, and Alex Shilo. I could not have completed this book without their efficient help. Jane Remme, in particular, played a pivotal role during the preparation of the manuscript and I want to acknowledge her major contributions.

My gratitude goes also to Meghan Cagley, who skillfully edited the manuscript and Nicole Hamon, who helped with administrative matters.

The literature review proved to be a gigantic task for a study of this scope and I am most indebted to the staff of the World Bank Group Library for their efficient help, in particular Turan A. Atay, Eliza J. Mcleod, Julia Y.B. Poblete, and Don A. Upendra.

Several colleagues read entire chapters and provide constructive comments. I am particularly grateful to Nada Chaya, Chloë Fèvre, Carl Haub, Charles H. Teller, and Giuseppe Zampaglione.

This book could never have been completed without the help of many others colleagues, librarians, friends, and family members. I want to thank Sara AdkinsBlanch, Lori S. Ashford, Isabelle Attané, Prospère R. Backiny-Yetna, Hubert Balique, Stan Bernstein, Kipper Blakeley, Ed Bos, Don Bundy, Martha M. Campbell, 
Yves Charbit, Sadia Afroze Chowdhury, Richard P. Cincotta, Julia Cleaver, MariaEugenia Cosio-Zavala, Jacques Crosnier, Monica Das Gupta, Henry P. David (1923-2009), John P. Davis, Antoine de Romanet de Beaune, Peter J. Donaldson, Yohana Dukhan, Enéas Gakusi, Patrick Gerland, Gannon Gillespie, Tom Goliber, Jean-Pierre Guengant, Davidson R. Gwatkin, Reem Hafez, Alain Holleville, Rachel Hoy Deussom, Rubina Hussain, Corinne Ilgun, Alan G. Johnston, Mary M. Kent, Monica Kerrigan, Marya Khan, Hans Küng, Rama Lakshminarayanan, Jean-Louis Lamboray, Gilles Landrivon, Michel-Louis Lévy, Anna Lipchitz, Elizabeth Lule, Wolfgang Lutz, Lallianzuali H. Malsawma, Robert Maurer, Alexandra May, Lionel May, Gisèle Maynard-Tucker, William P. McGreevey, Thomas W. Merrick, Michael Micklin, Vinod Mishra, Nicole Nardo, Rachel Nugent, Thomas F. O'Herron, Elio Omobono, Ok Pannenborg, Dudley L. Poston, Malcolm Potts, Stephanie Pozuelos, Hantamalala Rafalimanana, Alexander Ritter, Warren C. Robinson, Farzaneh Roudi-Fahimi, Elisabeth Sandor, Alex Schratz, Gilda Sedgh, Jeremy Shiffman, Susheela Singh, Richard Skolnik, Rhonda R. Smith, Agnès Soucat, John Stover, Toru Suzuki, Robert Toubon, Tyjen Tsai, Marcel Vekemans, Mechai Viravaidya, Christine Wattelar, Rebecca Wind, Guillaume Wunsch, and Kanako YamashitaAllen.

In many different ways, every person I contacted during the preparation of this volume provided help and offered comments, ideas, and suggestions. Needless to say, the remaining errors are entirely mine. 


\section{Contents}

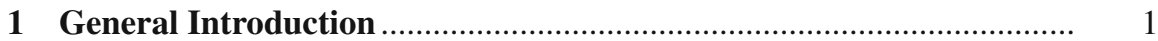

Overall Context of Population Policies..................................................... 2

Outline of the Book .................................................................................. 7

2 World Population Trends and Issues...................................................... 13

World Demographic Patterns and Trends ................................................ 14

Demographic and Epidemiological Transitions......................................... 20

Focus: The HIV/AIDS Epidemic ...................................................... 23

High, Medium, and Low Fertility Countries............................................... 25

Future Demographic Growth and Changing Age Structures ..................... 28

The Rise of International Migration …………………………………...... $\quad 32$

Old and New Demographic Issues......................................................... 37

Focus: Demographic Hotspots and "Cold Spots"............................... 38

Conclusion .................................................................................... 39

3 Population Policies Framework ………….......................................... 41

What Are Population Policies? ............................................................... 42

Malthusianism and Marxism..................................................................... 44

Population and Socioeconomic Development ........................................... 47

Focus: The Asian Demographic Dividends.......................................... $\quad 50$

Human Rights Concerns ....................................................................... 53

Intervention Variables and Policy Levers................................................ 55

Policy Processes, Instruments, and Actors …………………………….... 58

Implementation Modalities ...................................................................... 61

Focus: Sub-Saharan Policies smothered by Bureaucracy....................... 62

Implementation Challenges …………………………......................... 64

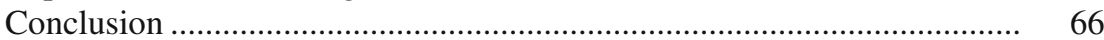

4 First Public Health and Population Programs ………........................... 67

Initial Efforts to Reduce Mortality ........................................................... $\quad 68$

Programs on Specific Diseases .............................................................. 71

The Expanded Program of Immunization................................................... 76 
Vanguard Family Planning Programs ……………………..................... 78

Expansion of Family Planning Efforts ....................................................... $\quad 84$

Focus: The Population Movement ........................................................ 85

Components of Family Planning Programs …………………………….... 87

Focus: Mechai Viravaidya, Activist Par Excellence .............................. 88

Conclusion ................................................................................ 90

5 Internationalization of Population Issues ………………………............. 91

International Population Paradigms ....................................................... 92

Focus: Changing Attitudes Toward Population Issues

in Colombia ................................................................................ 96

New Population Institutions.................................................................... 99

Focus: France's New Strides in International

Population Programs .................................................................... 101

World Population Conferences .................................................................. 105

New Developments and Old Controversies .............................................. 110

The Millennium Development Goals......................................................... 116

Improvements in Population Monitoring ................................................... 118

Focus: The International Drive to Collect Demographic Data ............. 118

The Availability of Population Projections ................................................. 121

Focus: Could India's Population reach Two Billion People? ................. 125

Conclusion .................................................................................... 126

6 Population Policies in Developing Countries ........................................ 129

Family Planning Spreads Around the World ......................................... 130

The Role of Induced Abortion ............................................................ 137

Focus: Induced Abortion and Menstrual Regulation in Vietnam........... 139

Toward Reproductive Rights and Reproductive Health............................. 141

Focus: The Scourge of Excision ....................................................... 142

The Broader Scope of Population Policies ................................................ 146

Focus: The Slow Maturation of Mexico's Population Policy................. 147

Gender Issues and Indirect Actions on Fertility ………………………..... 149

Policies on Urbanization and Internal and International Migration............ 153

Urbanization and Internal Migration.................................................... 153

Focus: Transmigration Programs in Indonesia .................................. 155

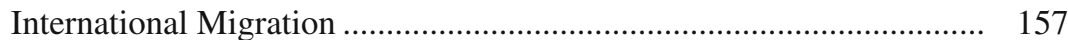

Population, Environment, and Sustainable Development ........................... 160

Focus: Haiti's Ecological Disaster ...................................................... 163

The Global Response to HIV/AIDS ........................................................ 165

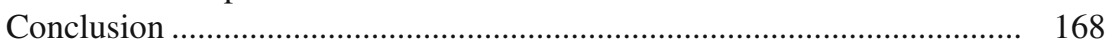

7 Population Policies in Developed Countries ........................................... 171

Sub-replacement Fertility................................................................. 172

Focus: From Anti-natalism to Pronatalism in Asia.............................. 177

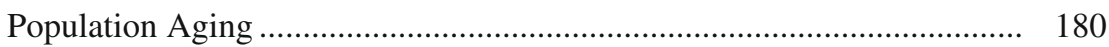

Immigration Policies ........................................................................... 186

Focus: The US as the Ultimate Immigration Country .......................... 189 
Population Policies vs. Socioeconomic Regulations ........................... 192

Family Policies........................................................................................ 195

Focus: Family Policies and Cultural Beliefs in Italy and Sweden ......... 198

Reaching a Policy Consensus .................................................................. 199

Focus: Roman Catholic Views on Modern Contraception .................... 202

Conclusion ................................................................................... 204

8 Effectiveness of Population Policies.................................................. 207

Measurement Methodology ............................................................. 208

Effectiveness of Family Planning Programs ........................................ 212

Focus: The Chinese Experiment................................................... 215

Broader Policy Interventions .................................................................... 219

Focus: Ethiopia's Strides to accelerate its Demographic

Transition ................................................................................ 220

Advocacy and Policy Dialogue ............................................................... 225

Experiences in Developed Countries ................................................... 227

Modeling Policy Interventions............................................................... 232

Focus: The Bongaarts Model of the Proximate

Determinants of Fertility ..................................................................... 233

Conclusion ................................................................................. 235

9 Future Prospects for Population Policies ............................................. 237

The New Demographic Landscape ......................................................... 238

Renewed Concerns: Climate Change, Poverty, Inequity,

and Security ................................................................................... 242

Priority Groups: Women, Adolescents, Old People, and Migrants .......... 249

The Challenge of Urbanization ............................................................... 254

New Bioethical and Gender Issues ....................................................... 260

Focus: "Missing” Girls................................................................. 261

Redefining Population Policies ............................................................. 263

Focus: Bangladesh's Fertility Transition in a Poor Setting .................. 265

Conclusion ..................................................................................... 268

General Conclusion....................................................................... 271

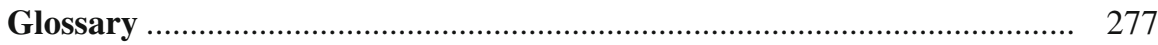

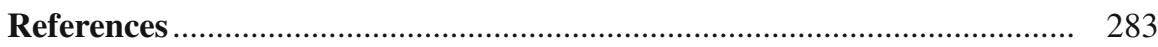

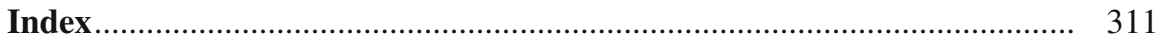





\section{List of Abbreviations}

\begin{tabular}{|c|c|}
\hline $\mathrm{ABC}$ & Abstain, Be faithful, use Condoms \\
\hline ACS & American Community Survey (US) \\
\hline AFD & $\begin{array}{l}\text { Agence française de développement (French Development } \\
\text { Agency) }\end{array}$ \\
\hline AIDS & Acquired Immunodeficiency Syndrome \\
\hline ART & Antiretroviral Therapy \\
\hline ARTs & Assisted Reproductive Technologies \\
\hline ASCOFAME & $\begin{array}{l}\text { Asociación Colombiana de Facultades de Medicina (Colombian } \\
\text { Association of Medical Schools) }\end{array}$ \\
\hline $\mathrm{BCC}$ & Behavior Change Communication \\
\hline BCG & Bacille Calmette-Guérin vaccine \\
\hline BEMFAM & $\begin{array}{l}\text { Bem-Estar Familiar no Brasil (Brazilian Society for Family } \\
\text { Welfare) }\end{array}$ \\
\hline BKKBN & $\begin{array}{l}\text { Badan Koordinasi Keluarga Berencana Nasional (Indonesian } \\
\text { Population and Family Information Network) }\end{array}$ \\
\hline bn & Billion \\
\hline BRAC & Bangladesh Rural Advancement Committee \\
\hline CASS & Chinese Academy of Social Sciences \\
\hline CBD & Community-Based Distribution \\
\hline $\mathrm{CDC}$ & Centers for Disease Control and Prevention (US) \\
\hline CGD & Center for Global Development (Washington, DC) \\
\hline $\mathrm{CHC}$ & Commune Health Center (Vietnam) \\
\hline CONAPO & $\begin{array}{l}\text { Consejo Nacional de Poblacion (Mexican National Council on } \\
\text { Population) }\end{array}$ \\
\hline CPR & Contraceptive Prevalence Rate \\
\hline CPS & Contraceptive Prevalence Survey \\
\hline DALY & Disability-Adjusted Life Year \\
\hline DDT & Dichloro-Diphenyl-Trichloroethane \\
\hline DFID & UK Department for International Development \\
\hline
\end{tabular}




$\begin{array}{ll}\text { DHS } & \text { Demographic and Health Survey } \\ \text { DPT } & \text { Diphtheria, Pertussis, and Tetanus } \\ \text { ECOSOC } & \text { UN Economic and Social Council } \\ \text { Ed. } & \text { Editor } \\ \text { Edit. } & \text { Edition } \\ \text { Eds. } & \text { Editors } \\ \text { ENGAGE } & \text { Eliminating National Gaps - Advancing Global Equity } \\ \text { EPI } & \text { Expanded Program on Immunization } \\ \text { EU } & \text { European Union } \\ \text { EUR } & \text { Euro } \\ \text { FGC/FGM } & \text { Female Genital Cutting/Mutilation } \\ \text { FIGO } & \text { International Federation of Gynecology and Obstetrics } \\ \text { FWA } & \text { Female Welfare Assistant (Bangladesh) } \\ \text { FWV } & \text { Female Welfare Visitor (Bangladesh) } \\ \text { GAVI } & \text { Global Alliance for Vaccines and Immunisation (now GAVI Alliance) } \\ \text { GDP } & \text { Gross Domestic Product } \\ \text { GEC } & \text { Global Economic Crisis (2008) } \\ \text { GF/ATM } & \text { Global Fund for AIDS, Tuberculosis, and Malaria } \\ \text { GIS } & \text { Geographic Information System } \\ \text { GIZ } & \text { Gesellschaft für Internationale Zusammenarbeit } \\ \text { GNI } & \text { Gross National Income } \\ \text { GPA } & \text { Global Program on AIDS } \\ \text { GTP } & \text { Growth and Transformation Plan (Ethiopia) } \\ \text { GTZ } & \text { Gesellschaft für Technische Zusammenarbeit (German Technical } \\ & \text { Cooperation Corporation) } \\ \text { HDI } & \text { Human Development Index } \\ \text { HIV } & \text { Human Immunodeficiency Virus } \\ \text { HNP } & \text { Health, Nutrition and Population } \\ \text { Ibid. } & \text { Ibidem (same place) } \\ \text { ICD } & \text { Infectious and Communicable Disease } \\ \text { ICDDR,B } & \text { International Centre for Diarrhoeal Disease Research, Bangladesh } \\ \text { ICPD } & \text { International Conference on Population and Development (Cairo 1994) } \\ \text { IEC } & \text { Information, Education, and Communication } \\ \text { IIASA } & \text { International Institute for Applied Systems Analysis } \\ \text { ILO } & \text { International Labour Organization } \\ \text { INED } & \text { Institut national d'études démographiques (French National } \\ & \text { Institute for Demographic Studies) } \\ \text { IOM } & \text { International Organization for Migration } \\ \text { IPCC } & \text { International Panel on Climate Change } \\ \text { IPPF } & \text { International Planned Parenthood Federation } \\ \text { IUD } & \text { Intra-Uterine Device } \\ & \text { Fis } \\ \end{array}$


IUSIPP International Union for the Scientific Investigation of Population Problems

IUSSP International Union for the Scientific Study of Population

IVF

JOICFP Japanese Organization for International Cooperation in Family Planning

$\mathrm{kg} \quad$ Kilogram

KPI Key Performance Indicator

LDC Least Developed Country

MAP Multi-Country HIV/AIDS Program for Africa

MDGs Millennium Development Goals

M\&E Monitoring and Evaluation

MMR Maternal Mortality Ratio

$\mathrm{m} \quad$ Million

MoFED Ministry of Finance and Economic Development (Ethiopia)

MPI Multidimensional Poverty Index

MR Menstrual Regulation

NAPA National Adaptation Programmes of Action

NAS US National Academy of Sciences

NCD Non-Communicable Disease

NGO Non-Governmental Organization

NIA US National Institute on Aging

NPP National Population Policy

OECD Organisation for Economic Co-operation and Development

ORT Oral Rehydration Therapy

PAA Population Association of America

PAC Post-Abortion Care

PAHO Pan American Health Organization

PAI Population Action International

PASDEP Plan for Accelerated and Sustained Development to End Poverty (Ethiopia)

PCC Population Crisis Committee

PDA Population and Community Development Association (Thailand)

PEPFAR US President's Emergency Plan for AIDS Relief

PHN Population, Health and Nutrition

PPP Purchase Power Parity

PRB Population Reference Bureau

PROFAMILIA Asociación Probienestar de la Familia Colombiana (Association for the Welfare of the Colombian Family)

PSIDS Pacific Small Island Developing States 


\begin{tabular}{ll} 
QALY & Quality-Adjusted Life Year \\
RAPID & Resources for the Awareness of Population Impact on Development \\
RBF & Results-Based Financing \\
RCT & Randomized Control Trial \\
RH & Reproductive Health \\
RTI & Reproductive Tract Infection \\
SARS & Severe Acute Respiratory Syndrome \\
SCAP & Supreme Commander of the Allied Powers (Japan) \\
SDPRP & Sustainable Development and Poverty Reduction Program (Ethiopia) \\
sq. km & Square kilometer \\
SSA & Sub-Saharan Africa \\
STD & Sexually Transmitted Disease \\
STI & Sexually Transmitted Infection \\
Suppl. & Supplement \\
TB & Tuberculosis \\
TFR & Total Fertility Rate \\
UK & United Kingdom of Great Britain and Northern Ireland \\
UN & United Nations \\
UNAIDS & The Joint United Nations Programme on HIV/AIDS \\
UNDP & United Nations Development Programme \\
UNESCO & United Nations Educational, Scientific and Cultural Organization \\
UNFCCC & United Nations Framework Convention on Climate Change \\
UNFPA & United Nations Population Fund \\
UNHCR & United Nations High Commissioner for Refugees \\
UNICEF & United Nations Children's Fund \\
UNODC & United Nations Office for Drugs and Crime \\
US & United States of America \\
USAID & US Agency for International Development \\
USD & US Dollar \\
USSR & Union of Soviet Socialist Republics \\
Vol. & Volume \\
VVF & Vesico-Vaginal Fistula \\
WDR & World Development Report (World Bank) \\
WFP & World Food Programme \\
WFS & World Fertility Survey \\
WHA & World Health Assembly \\
WHO & World Health Organization \\
WHS & World Health Survey \\
WPPA & World Population Plan of Action \\
\hline
\end{tabular}




\section{List of Figures and Maps}

Fig. $2.1 \quad$ Stages of the demographic transition........................................... 21

Fig. 2.2 Population pyramids of Niger, the US, and South Korea ............... 31

Map 2.1 Least developed countries ................................................................ 15

Map 2.2 The 18 big countries and the two potential big countries ............... 17

Map 2.3 Fertility levels across the world .................................................... 27 



\section{List of Tables}

Table 2.1 Population of the world, major development groups, and major areas, 1950 and 1975, and projections for 2010 and 2050 (2008 UN Medium variant).

Table 2.2 The 18 big countries: population in 2010 and projected population in 2025 and 2050 (2008 UN Medium variant)

Table 2.3 Life expectancy at birth (both sexes combined) for the world, major development groups, and major areas, years 2005-2010 and projected for 2045-2050 (2008 UN Medium variant)

Table 2.4 Total fertility rates for the world, major development groups, and major areas, years 1970-1975 and 2005-2010, and projected for 2045-2050 (2008 UN Medium variant).

Table 2.5 Main determinants of migration

Table 4.1 Expectancy of life at birth (both sexes combined) for the world, major development groups, and major areas, years 1950-1955 and 2000-2005.

Table 9.1 Key demographic indicators for Germany and Ethiopia, 2010 and projected for 2050 . 
